\title{
Reforming Indigenous policing: Understanding the context for change
}

\author{
Rick Ruddell* and John Kiedrowski ${ }^{\dagger}$
}

\begin{abstract}
Protests over the policing of Black and Indigenous people and people of Colour that started after the death of George Floyd in May 2020 at the hands of the Minneapolis police set the stage for debates about the role of the Canadian police in ensuring public safety. These protests have resulted in calls for police reforms, including reallocating police funding to other social spending. The public's attention has focused on urban policing, and there has been comparatively little focus on policing rural Indigenous communities. We address this gap in the literature, arguing that Indigenous policing is distinctively different than what happens in urban areas and the challenges posed in these places are unlike the ones municipal officers confront. We identify ten specific challenges that define the context for Indigenous policing that must be considered before reforms are undertaken. Implications for further research and policy development are identified, including founding a commission to oversee First Nations policing.
\end{abstract}

Key Words: Rural policing; police reform; police funding; Indigenous policing.

\section{INTRODUCTION}

Unrest and protests in Canada and the United States have drawn considerable attention to the policing of Black and Indigenous people and people of colour. The magnitude and duration of these protests is unprecedented in recent years. Although a number of Canadian scholars, including the Council of Canadian Academies (2014; 2019; CCA), had previously called for incremental reforms in policing, Vitale (2017, p. 30) argues that piecemeal changes have been ineffective and "any real agenda for police reform must replace police with empowered communities working to solve their own problems." Vitale's arguments are not new, and scholars such as Meares (2017) have long argued for policing to be abolished (McDowell \& Fernandez, 2018). While abolishing the police became a rallying point for American protesters, the number and magnitude of Canadian protests has been more subdued and the demands less extreme-although there has been some public support in favour of defunding the police (Angus Reid, 2020; Ipsos, 2020).

Despite there being less public support for defunding the police in Canada than in the United States, less than six months after Floyd's death a number of police reforms were introduced throughout Canada, including diverting police funding to other public services (Ho, 2020; Jones,
2020). Kempa (2014) observes that transformational changes in policing are often driven by economic restructuring, and during eras of economic insecurity, policymakers and the public question the nature of government interventions, definitions of public safety, and the role the police should play in maintaining order and ensuring public safety. While demands to defund the police in 2020 are different than what typically occurs during an economic downturn, discussions about the roles and responsibilities of the police are similar. There are, however, dangers that come with making knee-jerk reactions to long-term or systemic problems, as these reforms are seldom carried out in a thoughtful or planned manner, and most reformers fail to consider the ripple effects of change on other elements of the justice and social systems. Before proposing changes to the way Indigenous policing is carried out, we should first start with understanding the context in which this form of policing exists.

The lack of scholarship on rural or Indigenous policing is a serious impediment both to our understanding of these issues and to developing inventories of evidence-based crime-reduction practices. However, our focus on municipal policing is not surprising, as rural policing is out-of-sight and out-of-mind of most police scholars and rests on the margins of policing research (Ruddell, 2017; Wooff, 2017). In what follows, we identify ten contextual challenges in policing rural 
Indigenous communities that should be considered prior to introducing any reforms and present a suggestion for organizing and coordinating potential reforms.

\section{POLICING INDIGENOUS COMMUNITIES}

Indigenous peoples were involved in formal policing roles in their communities as far back as the 1880s. Bands were empowered to elect or appoint individuals who would carry out these roles, and they could also be appointed as constables under the Dominion Police Act (Dominion of Canada, 1889). Despite those fledgling steps towards self-determination, there is no shortage of scholarship on the troubled relationships between Indigenous Canadians and the police, and these shortcomings are identified in the reports of task forces and commissions released by the CCA (2019), DPRA Canada (2016), the National Inquiry into Missing and Murdered Indigenous Women and Girls (2019), and Quebec's Viens Commission (2019). These publications build on a long history of reports identifying the shortcomings in policing Indigenous communities. Between 1967 and 1990, for example, a total of 25 federal and provincial publications addressing the involvement of Indigenous persons with criminal justice systems were released (Alberta Government, 1991). A task force on policing carried out by Indian and Northern Affairs (1971) concluded:

That the Indian peoples on reserves require better and more adequate policing to meet the needs of their communities;

- That present policing on reserves is primarily complaintoriented;

- That much greater emphasis should be placed on preventative policing;

- That preventative policing on reserves will increase their sense of security and contribute to the growth of strong viable communities;

- That a new system of policing is required, broad and flexible enough to meet the particular needs of evolving communities in the different regions;

- That any system should offer to Indian peoples an opportunity to police themselves within the structure of an existing police force. (pp. 27-28)

Although written half a century ago — which is reflected in the language and paternalism used in the recommendations-the shortcomings identified in 1971 seem applicable today, raising the question of why there has been so little progress in delivering professional, dedicated, and culturally responsive policing to Indigenous communities, which was Public Safety Canada's (2019) mandate.

The challenges associated with responding to the distinctive needs of Indigenous peoples are not unique to Canada, and policymakers in other English-speaking nations colonized by the British, such as Australia (Office of the Aboriginal and Torres Strait Islander Social Justice Commissioner, 1996; Standing Committee of Attorneys' General Working Group on Indigenous Justice, 2010; The Allen Consulting Group, 2010), New Zealand (State Services Commission, 2012), and the United States (Morin \& Morin, 2019; Wakeling et al., 2001; Wells \& Falcone, 2008), have also struggled to provide responsive, effective, and unbiased policing (Kiedrowski, 2013). Scholars in these four nations have identified the overrepresentation of Indigenous peoples in their justice systems, from arrests to incarceration, and attribute some of this prevalence to discriminatory and racist practices (see a summary in Samuelson, 1993). What differentiates Canada from other nations with Indigenous populations colonized by the British is the introduction of the First Nations Policing Program (FNPP) in 1991 to provide a national-level framework for policing these communities (Solicitor General Canada, 1996). The following section describes the evolution of the FNPP.

\section{The Evolution of the First Nations Policing Program}

The FNPP is distinctive in English-speaking common law nations with high proportions of Indigenous peoples because of its comprehensive national strategy and cost-sharing arrangements. The FNPP is a discretionary and non-statutory transfer payment program in which tripartite agreements are made between Canada, the provinces/territories, and Indigenous communities (Office of the Auditor General of Canada, 2014; OAG). The FNPP provides 100\% funding for Indigenous communities to establish their own self-administered (SA) police service, much like a municipal police department. Under these arrangements, the federal government contributes $52 \%$ and the provincial/territorial governments contribute $48 \%$ of the funding. There are only 38 SA services, so most Indigenous communities contract with large police agencies, such as the Ontario Provincial Police (OPP), Royal Canadian Mounted Police (RCMP), or Sûreté du Québec (SQ) to provide policing services via community tripartite agreements (CTA). These arrangements were intended to increase culturally responsive policing, which has never been formally defined but is generally interpreted as increasing the proportion of Indigenous officers. A second key goal of introducing the FNPP was to enable First Nations to increase their self-determination by policing their communities. While First Nations have the capacity to form their own SA police services, only 59 of these agencies have been established and none founded after 2008.

Although the FNPP was founded with a great deal of optimism and good intentions, a series of evaluations reveals that the actual delivery of police services suffers from a number of shortcomings (Hunter-Courchene Consulting Group, 2014; OAG, 2014; Public Safety Canada, 2010; 2012; 2016). About one-third of the fledgling SA police services established after the introduction of the FNPP were disbanded, and Kiedrowski, Jones, and Ruddell (2017) question whether these agencies were set up to fail. They conclude that these organizations, like many other First Nations programs funded by provincial and federal governments, were treated with benign neglect and their struggles ignored.

There is growing agreement that a key shortcoming of SA policing is that Indigenous police services are not deemed essential services. Because they are defined as discretionary programs, they receive less funding than their municipal counterparts. Indigenous communities without an FNPP agreement are policed under the jurisdiction of the various provincial police acts. By contrast, for Indigenous communities with SA agreements, the policing service provides enhanced rather than core policing services (Clairmont, 2006; Murphy \& Clairmont, 1996). Core services are considered activities such as law enforcement, protection, intelligence, and 
service to communities. Enhanced services, on the other hand, are intended to advance community safety by addressing the root causes of criminal behaviour and include community engagement and mobilization, victim services, school visits, youth interactions, interagency cooperation, and liaison with the community (OAG, 2014).

While the term enhanced policing has not been formally used by the federal government since 2014, the issue of delivering enhanced policing services was examined by the OAG (2014, p. 13) with regard to the RCMP contract policing arrangements, who noted that, "In our view, the lack of clarity in the agreements and among the involved parties about what constitutes enhanced policing services-which the First Nations Policing Program is intended to fund - creates ambiguity in the delivery of those services." A similar argument can be extended to the SA policing agreements, and the challenge for these agencies is to provide core policing while being funded as an enhanced or supplemental service (DPRA Canada, 2016; Kiedrowski et al., 2017; Prairie Research Associates, 2006).

The issue of whether FNPP policing is a core or enhanced service leads to the question of whether this form of policing is an essential service. The federal government has not legislated policing as an essential service in Indigenous communities although policing is deemed essential in other areas of federal and provincial legislation (CCA, 2019; Promislow \& Metallic, 2018). This is a long-standing criticism of the FNPP, and the DPRA Canada (2016, p. 19) community consultations revealed that participants were critical of the FNPP, as "it has no formal legal basis," and "Without a clear statutory basis, policing is arbitrary and subject to a contribution program approach which tends to see services as discretionary." The First Nations Chiefs of Police Association (2017) unanimously passed a resolution to make First Nations policing an essential service. These criticisms resulted in the federal Public Safety Minister indicating that Indigenous policing must be made an essential service by developing a "legislative framework that ensures First Nations have the policing services they need and deserve" (Blair, 2020, p. 2; see also Bronskill, 2020). But like so many issues related to Indigenous peoples these promised reforms are slow in coming.

Police services working within the FNPP framework continue to adapt to the unmet needs and legitimate demands of Indigenous communities. The CCA (2019) points out that:

Current policing models are based on dated colonial structures in which police often operate separately from the communities they serve, rather than allowing themselves to be intertwined with a particular community and its values. Success in these models is often measured against a narrow set of metrics, such as incarceration rates and crime statistics, which are overgeneralized and affected by discriminatory and damaging societal attitudes. (p. 157)

The CCA (2019) report concludes that Canada's approach to Indigenous policing requires reforms, specifically acknowledging the impact of colonialism. The CCA recommends adopting a holistic approach to safety and well-being that recognizes the need to promote self-determination and Indigenous rights and laws, as well as the need for police to take a leadership role in mobilizing communities (p. xiii-xvii).
Since May 2020, there has been considerable attention placed on the need to reform policing, and there are demands to "get something done." Political and public demands to reform policing are not a new occurrence. Murphy (2004) points out that Canadian policing has been "characterized by growing political pressure for greater fiscal and operational accountability, escalating policing costs, expanding service demands, shrinking budgets, declining police growth and, ultimately, reduced police services" (p. 1). Even before the most recent crisis, a growing number of politicians, academics, policymakers, and members of advocacy groups were arguing that the traditional policing model should be redesigned, reengineered, reconfigured, or reinvented in light of contextual changes (see Corley et al., 2018). While there are gaps in our knowledge about the operational practices in Indigenous policing, we know that social problems, such as crime, are highly interconnected with unmet community needs in terms of addictions, physical and mental health, poverty, and unemployment. Thus, the problems related to policing are often symptomatic of larger community problems. Yet we must not forget that these communities also have strengths that can be leveraged to enhance well-being and community safety.

\section{TEN CHALLENGES CONFRONTING RURAL INDIGENOUS POLICING}

Although there are many factors that might inhibit providing more responsive and effective policing, the following section highlights ten issues that need to be acknowledged as part of the context in which rural Indigenous policing exists. As is the case with other complex social problems, many of these challenges are interrelated and it may be impossible to make significant headway on any one of these issues without addressing the others.

\section{A Small and Diverse Population Spread Throughout A Big Nation}

One of the foremost challenges for policing rural and remote Indigenous communities is the relatively small number of people living in these places. In 2019, there were about 440,000 persons living in 457 First Nations and Inuit communities served by police operating under 186 agreements with the FNPP (Mugford, 2020). Policing sparse populations spread throughout a large geographical area is a complex and costly undertaking. This is particularly relevant in the three northern territories, where the average population served by a police service is about 1,900 residents, compared with 9,000 people in the Provincial North and over 44,000 residents in southern communities (Allen \& Perrault, 2015).

In addition to Indigenous communities comprising small numbers of people spread across a vast territory, it is also important to acknowledge the diversity of Indigenous peoples. Although writing about Native Americans, the observations made by Wells and Falcone (2008, p. 218) are equally applicable to Canada, noting that:

Different tribes may have different names and geographic locations, but also different languages, 
different family structures, different economic systems, different governmental structures, different histories of military and political domination, different relationships to the surrounding non-Indian societies, different moral and religious beliefs, and distinctive cultural traditions. In analytical terms, this means that single global descriptive statements about "Indian culture" or "Indian policing" cannot be very descriptive since the world they seek to describe is not homogeneous or unitary.

While Indigenous peoples account for about $5 \%$ of Canada's population, O'Donnell and LaPointe (2019) report the rapid growth of this population, which rose $19.5 \%$ between 2011 and 2016 (p. 1). This rapid population growth has implications for the delivery of health, education, public safety, and social services in these communities.

\section{Community Well-Being}

Indigenous and Northern Affairs Canada (2020) recognizes 619 First Nations, and while some are very prosperous places, the average First Nation has entrenched social problems higher than the national average. A review of the community well-being (CWB) index, which is an indicator of education, labour force activity, per capita income, and housing from 1981 to 2016 reveals that the CWB average for Indigenous communities was 58.4 while the average for non-Indigenous communities was 77.5 out of a possible 100 (Indigenous and Northern Affairs Canada, 2019, p. 5). Not surprisingly, Ruddell et al. (2014) and MacDonald et al. (2019) found that the CWB tends to decrease as communities become more distant from urban centres. Although well-being has been increasing in First Nations since the 1980s, the gap between First Nations and non-Indigenous communities has remained about the same.

Rural Indigenous communities may be more vulnerable to economic downturns than non-Indigenous municipalities. Ruddell and Jones (2014) observe that in tough economic times, social programs are often the first to be cut, and this has an impact on community well-being and public safety. Montgomery and Griffiths (2017) note that "when governments cut the numbers of social workers, mental health workers, funding for shelter beds and for specialized facilities for the mentally ill, there is a direct impact on the demands placed on the police resources" (p. 9). Poverty and unemployment are only part of the challenges that many communities face. When asked about indicators of community dysfunction, responses from over 700 officers policing Indigenous communities throughout Canada in December 2014 reveal that $85.5 \%$ of them reported that family violence was a somewhat or very serious problem, $81.8 \%$ said that child welfare was a somewhat or very serious problem, and $91.7 \%$ indicated that alcohol or drug misuse was a somewhat or very serious problem (see Jones et al., 2019). Ruddell and Jones (2020) found that officers working in these communities developed a style of policing that was responsive to these conditions.

Community well-being is also eroded by high suicide rates, and 55\% of the police officers in the Jones et al. (2019) survey indicated that suicide was a somewhat or very serious problem. Other research substantiates that observation, as suicide rates for Indigenous Canadians are three times higher than for non-Indigenous people (Kumar \& Tjepkema, 2019). With respect to Indigenous peoples living on-reserve, Kumar and Tjepkema (2019) found that they were about twice as likely to die by suicide, but those researchers also note that over $60 \%$ of First Nations had no suicides (p. 5). One question asked of the officers policing Indigenous communities in 1996, 2007, and 2014 was whether they agreed that dealing with mostly unsolvable problems was common. In all three waves of the survey more than four out of five respondents somewhat or strongly agreed that the problems they confronted were unsolvable $(80 \%, 86.3 \%$, and $84.5 \%$ respectively).

3. High Rates of Police-Reported Crime and Victimization While some First Nations have rates of crime that are lower than or comparable with other Canadian municipalities, it has long been recognized that rates of crime are disproportionately high in Indigenous communities. Brzozowski et al. (2006) found that "on-reserve crime rates were about three times higher than rates in the rest of Canada," and that "the difference was even greater for violent crime, with an on-reserve rate that was eight times the violent crime rate for the rest of the country" (p. 1). In one of the few national-level studies examining crime rates in FNPP communities, Lithopoulos (2016) reports that overall crime rates were 3.7 times higher than the national average, while rates of violent crime were 6.7 times higher than the national average. Analyses of the crime severity index-an indicator of the volume and seriousness of crime-reveal they were highest in the most remote jurisdictions (Public Safety Canada, 2012; Ruddell et al., 2014). Last, Allen (2020, p. 3) reports that in the 182 communities where the majority of the population is Indigenous, crime rates were "six times higher than crime rates reported by police services that served primarily non-Indigenous populations" and violent crime rates were almost nine times higher.

Using the results from the survey conducted by Jones et al. (2019) reported above, $60.4 \%$ of officers policing Indigenous communities indicated that high levels of property crime was a somewhat or very serious problem, while over two-thirds (67.8\%) said that high levels of violent crime were a somewhat or very serious problem. High violent crime rates are also associated with high rates of victimization, as most incidents involve Indigenous perpetrators and victims. Boyce (2016) reports that the overall victimization rate of Indigenous people was more than twice that of non-Indigenous people (p. 3). Subsequent research has found that Indigenous girls and women and Northern residents are more vulnerable to victimization and unwanted sexual behaviours (Nilson \& Mantello, 2019; Perreault, 2020; Rotenberg, 2019). Roy and Marcellus (2019) observe that Indigenous people were about five times more likely than non-Indigenous people to be homicide victims (p. 30).

There is growing awareness that physical and sexual victimization can have significant psychological impacts upon an individual and is associated with substance abuse, lower lifetime earnings, diminished physical health, and involvement in crime (Menard, 2002). Consequently, these 
high rates of victimization and traumatization can further decrease community well-being, contributing to crime in an ongoing and self-perpetuating cycle.

\section{Lack of Indigenous Policing Research}

Murphy (1999) observes that "Democratic policing requires research-based information and knowledge so that citizens and their governments know what the police do, how they do it, and with what effect" (p. 205). There is a dearth of research on rural policing, and not much has changed since Lithopoulos and Ruddell (2013) argued that Indigenous policing was the most underresearched aspect of Canadian law enforcement. They identified the need to develop a research-based inventory of best practices in rural and Indigenous policing. Kiedrowski (2013) points out that while most previous studies of Indigenous policing in Canada are descriptive, the extent, nature, effectiveness, and efficiencies of Indigenous policing have received scant attention in academic research or government-funded evaluations.

In order to test the proposition that Indigenous policing is under-studied, we carried out a review of Social Sciences and Humanities Research Council (2020; SSHRC)-funded research and found that from 2000 to 2019, SSHRC issued $\$ 7,046,962$ in total grants and fellowships for 256 topics related to policing. Of this total, three topics-or about one percentwas awarded for projects directly on Indigenous policing.

For the reasons described above regarding diversity of the population, the outcomes of research might also be dependent upon what group(s) of Indigenous peoples are studied. Wells and Falcone (2008, p. 218) contend that "case studies of a single tribe or tribal group-no matter how well done-cannot be confidently generalized to be true of all Indian communities, at least not without a systematic survey to document what is true in other tribal contexts." That observation should not discourage us from conducting Indigenous police research, but we should also be aware that our findings might not be representative of all First Nations peoples, including people of Inuit and Métis ancestry.

\section{Chronic Under-Funding of SA Police Services}

Although a number of Canadian municipalities are in the process of reallocating police funding to social service agencies, a series of evaluations found that SA police services are underfunded. Writing about these agencies, the OAG (2014) observes that the "FNPP is not adequately designed to deliver and does not adequately ensure that policing services are delivered in a manner consistent with the principles of the First Nations Policing Policy that we examined" (Chapter 5, Conclusion 5.72). Inadequate and short-term funding arrangements make it difficult for SA police services to deliver effective services or make long-term plans.

Although longer-term funding arrangements were introduced in 2018, the First Nations Chiefs of Police Association argues that their agencies continue to be underfunded (Deer, 2019). The impact of funding shortfalls is exacerbated in communities experiencing high crime rates and when first responders are expected to carry out duties not typically re- quired of municipal police services (Viens Commission, 2019, p. 268). Inadequate funding has also resulted in a wage gap between officers working in SA services and their municipal counterparts, which can contribute to problems retaining officers (see below). Moreover, officers are sometimes using outdated equipment, such as wearing expired body armour, and many SA services lack the physical infrastructure-such as detachment buildings in remote communities-required to ensure the safety of officers and people detained in custody (Viens Commission, 2019).

Not only is FNPP funding inadequate, but there has been a lack of consistency in the per capita funding allocated to different SA police services. Kiedrowski et al. (2016) examined funding for ten SA police services and found a substantial interprovincial variation in per capita police funding. Inconsistent with expectations, geographic isolation does not appear to be a factor in allocating funds to these agencies. The three SA agencies with the highest per capita funding, for instance, are all located in communities close to urban areas. By contrast, the agencies in the two most isolated communities received less per capita funding. When asked about allocating funding, a police executive from an SA service stated that "the only thing consistent about the FNPP is the inconsistency in funding policing services" (Kiedrowski et al., 2016, p. 17).

\section{Expectations of Officers Policing Indigenous Com- munities}

Most Indigenous communities are policed by the RCMP, and Leuprecht $(2017 ; 2020)$ and Watt $(2008)$ have described the shortcomings of that organization's contract policing arrangements and institutional culture. Although acknowledging that officer misconduct can flourish in a dysfunctional organizational culture, we must also recognize the high expectations placed on the front-line officers policing Indigenous communities regardless of whether they are employed by the OPP, SQ, RCMP, or an SA police service. Many of them are working in their first policing jobs, and they are often in their early twenties when first deployed. They soon learn that, in the absence of other health and social services, they are required to intervene in situations that their urban counterparts are not expected to confront.

In many rural and remote communities, for instance, there may be no full-time social worker, public health nurse, or addictions worker to respond to people experiencing psychological distress, going through withdrawal, engaging in a family conflict, or requiring other immediate supports for a personal crisis. Some mental health and social service professionals travel to these places and are only available a few days a month, and it may take hours to access crisis services in small towns or First Nations. As no alternatives exist, officers in remote communities are expected to devote a significant proportion of their time to what they call social work activities (Huey \& Ricciardelli, 2015). Few cadets, however, receive more than a few hours of academy training preparing them for these roles (Coleman \& Cotton, 2010). One possible technological solution to this shortcoming is using body-worn cameras to livestream interactions between the police and mental health professionals, who can provide expert advice to the officers (Canadian Broadcasting Corporation, 2020; CBC). 
One of the goals of the FNPP was to increase the prevalence of Indigenous officers, but survey results from 1996, 2006, and 2014 show that the proportion of Indigenous officers has been decreasing over time; from $90 \%$ in 1996 to $27 \%$ in 2014 (although this finding may be an outcome of the officers participating in these studies, see Jones et al., 2019). Marcoux et al. (2016) found that, in Nunavut, where the population was almost $90 \%$ Indigenous, only $12 \%$ of the police officers were of Indigenous ancestry, and over $80 \%$ of the police in the Northwest Territories were White. One question that emerges from those observations is why the number of Indigenous officers is decreasing.

One reason for decreasing numbers of Indigenous officers could be related to problems in retaining personnel. There are very high levels of turnover in some SA agencies, and Rogers (2019, para. 2) observes that the Kativik Regional Police Force in northern Quebec is "considered fully staffed with 65 officers" but observes that "an average of 70 officers leave the force each year-more than the number the force even employs at one time" (para. 5). New officers often treat jobs with SA agencies as stepping stones to careers with larger police services that offer higher salaries and more diverse occupational opportunities throughout their careers. Yet there are also problems retaining officers in larger police services such as the OPP, RCMP, or SQ in rural and remote postings. These officers are said to "put in their time, save some money, but eventually apply for a promotion and leave" (Leuprecht, 2017, p. 28).

High turnover rates impact service delivery, as it often takes a year or longer before officers develop a solid understanding of general duty policing, not to mention a community's culture and dynamics. As a result, when turnover rates are high, it lowers the average experience level of the entire agency, which can also lower the agency's effectiveness. Mass turnover also has an impact on organizational efficacy, as the time, energy, and resources of an agency's leadership are focused on recruiting, training, and retaining officers rather than crime prevention activities.

\section{Community Expectations}

When asked about their expectations of the police, Indigenous stakeholders told DPRA Canada (2016) researchers they needed quick responses to their calls, they wanted the police to help solve their problems, and they wanted those problems resolved in a respectful manner. Similar expectations were expressed by community members from the Tk'emlúps te Secwépemc First Nation in the Kamloops area, who said that professionalism, quick response times to calls for service, police visibility, and maintaining independence from inappropriate political influence were key priorities (Kiedrowski, 2017). There is, however, some variation within the nation about different policing priorities, with Inuit respondents indicating that officers lacking maturity, as well as arrogant and/or aggressive officers who had no real interest in Northern peoples, were barriers to establishing collaborative relationships (Marchand et al., 2020). Interviews with Indigenous people in Nova Scotia reveal that many of these respondents mistrust the police and feel that officers did not protect their families when they failed to conduct proper investigations (McMillan et al., 2020). Nilson and Mantello (2019) carried out interviews with Indigenous peoples and subject matter experts from across the nation to determine the key ingredients to effective collaboration between their communities and the police. They found that, in order for this to happen, the police must secure community confidence and legitimacy and seek shared goals and values. Altogether, these results suggest that priorities about policing arrangements may vary according to the organizations providing police services, as well as the histories between those agencies and the First Nations they serve.

One way to gauge the well-being of police and community relationships is to examine the number of complaints about the police arising in Indigenous communities. Kiedrowski et al. (2020) analyzed the number of complaints filed with the Civilian Review and Complaints Commission for the RCMP in Alberta, Manitoba, and Saskatchewan First Nations for a three-year period. They found high rates of on-reserve complaints relative to the small populations in these places. Those results are not surprising given the higher-than-average levels of crime-and therefore interactions of community members with the police-in some First Nations in the prairie provinces. Those researchers, however, also found that organizational barriers to lodging and investigating complaints existed. Furthermore, a lack of demographic information about the people launching the complaints makes it difficult to make meaningful statements about the relationships between the police and the community members they serve.

One longstanding challenge in policing Indigenous communities, whether it is by contracted or SA services, is balancing under- and over-policing. Manitoba's Aboriginal Justice Implementation Commission (2001) observes that under- and over-policing can occur simultaneously. According to the Commission, over-policing results in higher levels of contact with the police-usually for minor offences-that non-Indigenous people do not experience. Under-policing, by contrast, occurs when police are less engaged in crime prevention activities and are only perceived as coming to a community when investigating crimes (Aboriginal Justice Implementation Commission, 2001). Members of the Commission observe that under- and over-policing are consequences of officers adopting a narrow view of policing based on enforcement rather than a broader approach addressing the underlying community problems that contribute to crime.

Balancing under- and over-policing can become a contentious issue in rural and remote communities. Officers responding to calls for service, for example, use their discretion and often caution or warn someone who has committed a crime rather than arresting them. But what if the people who called the police believe the wrongdoer should receive a tougher sanction? Brunson (2020) explains that underpolicing leaves people feeling underserved and unsafe, potentially reducing police legitimacy and fuelling the public's reluctance to cooperate with the police. Moreover, if calling the police is perceived to be a waste of time, some individuals may bypass involving them altogether and handle matters themselves by destroying property or physically harming someone who has wronged them, what Black (1983) has termed "self-help." There is some speculation that pullbacks of RCMP policing on First Nations in the 1960s and 1970s in 
Ontario and Quebec contributed to higher rates of crime in these places. Although there is no scholarship conclusively supporting that contention, examining the outcomes of those cutbacks in police services may provide us with insights into the historical impacts of defunding Indigenous policing.

\section{The Fragility of Stand-Alone Self-Administered Police Services}

Soon after the establishment of the FNPP there was a rush to establish new SA services; 58 were founded prior to 2000 , although 20 of these disbanded between 2000 and 2010. Lithopoulos (2016) observes that stand-alone police services with fewer than ten officers were more vulnerable to disbanding than their larger counterparts. Small police services, regardless of the populations they serve, are often disadvantaged because of their inability to benefit from economies of scale to reduce costs, and rural policing is more expensive to deliver due to the need to serve large sparsely populated geographical areas. This is especially true in remote communities lacking year-round roads, as police equipment-such as vehicles, fuel, and parts - must be transported by boat or plane (Ruddell et al., 2014). Personnel costs are also higher in these agencies because of the frequent requirement for officers to be on-call, the need to transport arrestees or prisoners lengthy distances to court appearances, and costs related to overtime and salary supplements for remote postings (Leuprecht, 2017; Ruddell, 2017; Ruddell et al., 2014).

The vulnerability of stand-alone police services to disbanding is consistent with what has been happening across Canada since the 1980s, as smaller non-Indigenous police services are also disbanding and several smaller stand-alone agencies will sometimes regionalize to form a single agency (Lithopoulos, 2015). Several large SA regional police services have emerged, including Ontario's Nishnawbe Aski Police Service (NAPS), founded in 1994. This police service's 134 officers and 30 civilian personnel serve 34 communities spread across a geographical area that covers about two-thirds of the province. Given the success of this agency, this regional approach may serve as a model for the rest of the nation.

Kiedrowski and colleagues (2015) and DPRA Canada (2016, pp. 19-20) researchers identify several bureaucratic and legislative barriers to regionalizing Indigenous police services, including limiting some SA policing to on-reserve activities. These restrictions reduce the effectiveness of these agencies in responding to crimes that may originate on First Nations but extend beyond their geographical boundaries. These jurisdictional restrictions originate with the federal Indian Act, which allows First Nations to establish police services but with officers appointed under provincial Police Service Acts, which give First Nations constables their peace officer status. Geographical factors also reduce the likelihood of regionalization since many First Nations are hundreds of kilometers from the next nearest First Nation, making it difficult to establish a regional operation.

\section{Civilianization and Indigenous Policing}

Kiedrowski et al. (2019) describe how the proportion of civilian employees of Canadian police services has been increasing and how these personnel are carrying out duties formerly performed by sworn officers, including crime prevention duties and responding to antisocial behaviour and disorder. Indigenous personnel-who had limited police powers-were introduced by the 1880s to support the formal police (Jacobs, 2012). These officials became known as band constables by the 1960s, their primary role being, on the one hand, to form bridges between sworn police officers and the First Nations they served and, on the other, to enforce bylaws and engage in crime prevention activities (Clairmont, 2006). Rigakos (2008) found that these non-sworn officials play an important role in some First Nations communities by increasing police visibility, improving response times, enhancing community relations with the police, and increasing the flow of information from sworn officers to community members (p. 7).

Since 2010, a growing number of civilians have been deployed on First Nations as community safety officers (CSO), peacemakers, First Nations safety officers, or special constables. DPRA Canada (2016) researchers found these officials in communities lacking formal police services sometimes engaged in police activities, which may place their band at some risk of liability (p. 19). Rigakos (2008) found that one of the shortcomings limiting the effectiveness of these officials was their lack of training. Since Rigakos's research was published, a number of colleges have begun offering academic programs to prepare individuals for CSO and peacemaking roles.

Although there is an intuitive appeal to diverting nonemergency and low-risk activities to non-sworn personnel, there is a lack of research about their effectiveness in Canada. Sworn officers can harbour ambivalent feelings towards these civilian personnel, who, while they provide welcome support, received less respect than sworn officers within the organizations (Kiedrowski et al., 2019). Moreover, the researchers also found that these civilian positions were the first to be cut in response to budget downturns in the United Kingdom. Alaska's Public Safety Officer Program, which deploys uniformed non-sworn officials to police remote Alaskan villages, may be a cautionary tale for Canada with respect to placing high expectations on these community residents to increase a community's informal controls. Like band constables in Canada, these officials can play an important role in order maintenance in rural and remote places, but the effectiveness of the Alaskan officers suffers from a lack of funding and organizational support (Hopkins, 2019). As a result, if we are considering expanding the roles of non-sworn officials in Indigenous communities, that support should be adequate to do their jobs and be sustainable over time.

\section{Officer Risks}

Officers policing Indigenous communities are at a higher risk of physical victimization or unintentional injuries (such as being involved in traffic collisions), and policing rural, Northern, Indigenous, and remote communities exerts a greater psychological toll on these officers than on their municipal counterparts (Carleton et al., 2018a). Ricciardelli's (2018) interviews with officers policing rural communities reveal that they understand the 
inherent risks of this type of policing but grapple with the realities of working in unsafe conditions, for example when there is chronic understaffing, when they have to use compromised equipment, or when a police service lacks the physical infrastructure to enhance officer safety, such as a detachment with holding cells (p. 433). Having sufficient funding and organizational supports would allay many of their concerns.

Understaffing, high turnover, working in isolation, and responding to high levels of antisocial behaviours, crime, and victimization contribute to operational stress injuries. Carleton and colleagues (2018a) examined surveys from almost 6,000 Canadian public safety personnel about their reactions to job-related stressors. These researchers found that over one-half of RCMP officers report having one or more symptoms of mental health disorders such as anxiety, depression, alcohol abuse, or post-traumatic stress disorder. Rural officers were also more likely than their urban counterparts to report suicidal ideation and having a plan to kill themselves, and RCMP officers were more likely than municipal officers to attempt suicide (Carleton et al., 2018b).

Police officers are also at high risk of victimization, and officers working in some rural and remote communities are at elevated risk. For example, between 2013 and 2019, there were 421 assaults per year, on average, on Nunavik police officers (Nunavik Statistics, 2020). As there was an average of about 80 officers per year employed during that era, it suggests that, on average, an officer was assaulted more than five times per year. Ruddell (2017) found that rural officers were about four times more likely to be killed on the job-from unintentional injuries as well as being murdered-than their counterparts working for municipal police services.

\section{POLICE REFORMS AND THE FUTURE OF INDIGENOUS POLICING}

Polls reveal that the public's trust and confidence in the police, courts, and corrections is waning, although it is the police-as one of the most visible forms of the criminal justice systemwho have received most of the public's attention since the death of George Floyd (Angus Reid, 2020; Ipsos, 2020). Our commentary focuses on contextual changes in rural Indigenous policing in order to better understand the challenges SA and contract policing organizations must overcome in order to deliver good policing. Although the FNPP was introduced to provide a national framework to deliver Indigenous policing, there is growing recognition of shortcomings in both the funding arrangements and the manner that contracted and SA policing services are delivered (CCA, 2019; Deer, 2019; Kiedrowski et al., 2017; Leuprecht, 2017; 2020). Having identified the changing context for Indigenous policing, we found that many stakeholders are critical of the existing policing model. There is far less agreement, however, about how the police should respond to these challenges, the need for reform, what changes should be enacted, and how these proposed reforms will be planned, funded, implemented, and overseen.

Predating the 2020 crisis, police scholars were already documenting the need for changes in policing. For example, Corley et al. (2019) identified the changing policing environment in Canada and found that:
Most policy-makers, police leaders and scholars would correctly predict that the next call for reforms will be driven by an economic, political, or legal crisis, or a highly publicized case of police misconduct or mistake. When these crises occur reformers advocate for rapid changes to police practices and are frustrated when changes do not occur, when reforms are incremental rather than revolutionary, or if the status quo prevails. Our knowledge of organizational change, however, tells us that knee-jerk changes in law or policy seldom have the desired results and poorly planned and implemented reforms can result in unforeseen outcomes. Instead, most police scholars suggest that potential reforms be based on a long-term strategy that carefully considers the external and internal organizational environments, be properly resourced, and be the end product of consultation that is carried out by police leaders who secure the buy-in and participation of reform-weary officers. (pp. 37-38)

Although policing Indigenous communities comes with many challenges, we know very little about what happens in these places, and an ongoing concern is that the one-sizefits-all approach offered by large policing agencies, such as the OPP, RCMP, or SQ, is not always applicable nor entirely responsive to the needs of these diverse communities.

Another key finding in recent police scholarship is the recognition that public safety is not solely dependent upon the police: community and non-enforcement agencies play an important role in crime prevention (CCA, 2014; 2019). One question emerging from that observation is how we can build on existing community strengths and the presence of other organizations to enhance community well-being and public safety. The well-being of Indigenous peoples seems to be a low priority for the federal government: if First Nations residents cannot access safe drinking water, how do we deliver something inherently more complex, such as providing effective, responsive, and culturally appropriate policing?

If provincial or federal police agencies are not able to meet the needs of Indigenous communities, some believe that the most effective strategy to policing these places might be delivered by large SA agencies serving entire regions, enabling them to benefit from economies of scale, providing more lateral and promotional opportunities for their personnel (and thereby reducing turnover), and increasing the organizational stability of these agencies. It is important to note that no newly founded SA agencies have been established since 2008, although a number of communities have expressed interest in founding new agencies. Both expanding the number of SA agencies and facilitating their growth as regional operations would enable a greater number of Indigenous communities to exercise self-determination over their justice systems.

\section{The Devolution of Policing Services to Indigenous Communities}

There is no shortage of scholarship showing the shortcomings of the FNPP, originally introduced as an innovative approach to increase the effectiveness of policing Indigenous communities (CCA, 2019; DPRA Canada, 2016; National Inquiry into 
Missing and Murdered Indigenous Women and Girls, 2019; OAG, 2014; Public Safety Canada, 2010; 2012; 2016; Viens Commission, 2019). Our commentary identified ten challenges and/or shortcomings associated with the current approach to Indigenous policing. We question whether an entirely new model to serving these places should be considered, given the changes in First Nations governance, including Court decisions and government policies, giving First Nations more control over their lands, financing, and the allocation of those resources.

Since the FNPP was introduced, for example, the Supreme Court of Canada has made decisions increasing the ability of First Nations to exercise their self-determination with respect to issues such as resources (R. v. Sparrow, 1990; $R$. v. Marshall, 1999), land titles (Delgamuukw v. British Columbia, 1997; Tsilhqot'in Nation v. British Columbia, 2014), and selfgovernment (R. v. Van der Peet, 1996; R. v Pamajewon, 1996). Furthermore, the federal government has been transferring various programs to Indigenous communities to extend their control over the management of their lands (First Nations Land Management Act), property taxation and financing for infrastructure and economic development (First Nations Fiscal Management Act), and health (First Nations Health Authority), and they announced the creation of an Indigenous Fire Marshall Office (Indigenous Services Canada, 2019).

The federal government continues to advance reconciliation with Indigenous peoples by transferring the delivery of various health, educational, and social services to Indigenous control (Government of Canada, 2019; Indigenous Services Canada, 2019). In addition, in the final report of the National Inquiry into Missing and Murdered Indigenous Women and Girls (2019), the Commissioners made a series of recommendations to improve Indigenous policing that include the following: creating a civilian oversight body with jurisdiction to audit Indigenous police services and investigate claims of police misconduct; building the relationships between the police and Indigenous peoples; reviewing and revising policies and procedures to ensure service delivery that is culturally appropriate; increasing recruitment of Indigenous peoples for policing; and building capacity and partnership with other agencies working in Indigenous communities to address crime and related social problems.

In keeping with the findings reported above, it may be time to establish a new national policing model designed to better meet the needs and demands of Indigenous communities and based on the lessons learned in the past three decades of the FNPP. One possible mechanism to carry out this change is for the federal government to transfer the delivery of Indigenous policing to a national-level commission responsible for the planning, funding, delivery, and oversight of Indigenous policing. Such an agency can become responsible for the operations and policies associated with the current FNPP, including the delivery of services to support the FNPP, fund the research and development of crime prevention programs, and provide oversight of those agencies. Such a commission would be in a better position to address how to best police First Nations communities in a culturally appropriate manner. This approach may also revisit the funding model for Indigenous policing to make it similar to the way policing in off-reserve communities is funded. The proposed commission may also be responsible for overseeing the investigation of police-related complaints for persons residing in First Nations communities, thus centralizing complaints to one body.

\section{CONCLUSION}

Almost half a century ago, the Solicitor General for Ontario (1974) observed that "the police service provided to Indian Bands has not been of a standard as high as that provided to most communities in the province, a standard of service to which they are equally entitled" (p. 59). Despite the introduction of the FNPP, there is a growing realization that the people living in a large proportion of Indigenous communities do not receive policing that is comparable to what other Canadians receive. The issues addressed in this commentary represent only the tip of the iceberg when it comes to the challenges of policing rural and remote Indigenous communities. The existing FNPP framework has not succeeded in ameliorating these shortcomings, and it may be time to consider other options founded on appropriate funding, community participation, a reliance upon evidence-based policing practices, and self-determination.

\section{CONFLICT OF INTEREST DISCLOSURES}

The authors declare that there are no conflicts of interest.

\section{AUTHOR AFFILIATIONS}

*Justice Studies, University of Regina, Regina, SK; ${ }^{+}$Compliance Strategy Group, Ottawa, ON.

\section{REFERENCES}

Aboriginal Justice Implementation Commission. (2001). Final report of the Aboriginal Justice Implementation Commission. Winnipeg: Author.

Alberta Government. (1991). Justice on trial: Report of the task force on the criminal justice system and its impact on the Indian and Metis people of Alberta. Retrieved from https://open.alberta.ca/publications/1369434

Allen, M. (2020). Crime reported by police serving areas where the majority of the population is Indigenous, 2018. Ottawa: Canadian Centre for Justice Statistics.

Allen, M., \& Perreault, S. (2015). Police-reported crime in Canada's provincial north and territories, 2013. Ottawa: Canadian Centre for Justice Statistics.

Angus Reid. (2020). Policing in Canada: Major study reveals four mindsets driving current opinions and future policy preferences. Retrieved from http://angusreid.org/policing-perspectives-canada-rcmp/

Black, D. (1983). Crime as social control. American Sociological Review, $48(1), 34-45$.

Blair, B. (2020). Standing committee on public safety and national security. Retrieved from https://www.ourcommons.ca/Content/ Committee/431/SECU/Evidence/EV10819343/SECUEV07-E.PDF

Boyce, J. (2016). Victimization of Aboriginal people in Canada, 2014. Ottawa: Canadian Centre for Justice Statistics.

Bronskill, J. (2020). Feds will make First Nations policing an essential service. National Observer. Retrieved from https://www.national observer.com/2020/06/24/news/feds-will-make-first-nationspolicing-essential-service

Brunson, R. K. (2020, June 12). Protests focus on over-policing. But underpolicing is also deadly. The Washington Post. Retrieved from https:// wWw.washingtonpost.com

Brzozowski, J., Taylor-Butts, A., \& Johnson, S. (2006). Victimization and offending among the Aboriginal population in Canada. Ottawa: Canadian Centre for Justice Statistics. 
Canadian Broadcasting Corporation (CBC). (2020). Fredericton police to use body cams for mental health calls. CBC News. Retrieved from https://www.cbc.ca/news/canada/new-brunswick/policebody-cam-mental-health-pilot-1.5767961

Carleton, R. N., Afifi, T. O., Turner, S., Taillieu, T., Duranceau, S., LeBouthillier, D. M. ... Asmundson, G. J. G. (2018a). Mental health disorder symptoms among public safety personnel in Canada. The Canadian Journal of Psychiatry, 63(1), 54-64.

Carleton, R. N., Afifi, T. O., Turner, S., Taillieu, T., LeBouthillier, D. M., Duranceau, S., ... Asmundson, G. J. G. (2018b). Suicidal ideation, plans, and attempts among public safety personnel in Canada. Canadian Psychology, 59(3), 220-231.

Clairmont, D. (2006). Aboriginal policing in Canada: An overview of developments in First Nations. Halifax, NS: Atlantic Institute of Criminology, Dalhousie University.

Coleman, T. G., \& Cotton, D. (2010). Police interactions with persons with a mental illness: Police learning in the environment of contemporary policing. Ottawa: Mental Health Commission of Canada.

Corley, C., Reber, M., Ruddell, R., Lins, C., Thorne, D., Catte, R., \& Brown, C. (2019). Provincial policing in Saskatchewan: An independent review from a values lens. Saskatoon: Community Safety Knowledge Alliance.

Council of Canadian Academies (CCA). (2014). Policing Canada in the 21 st century: New policing for new challenges. Ottawa: Author.

Council of Canadian Academies (CCA). (2019). Toward peace, harmony, and well-being: Policing in Indigenous communities. Ottawa: Author.

Deer, J. (2019). Underfunded and under-resourced, Indigenous police services struggle with MMIWG cases. CBC News. Retrieved from https://www.cbc.ca/news/indigenous/mmiwg-indigenous-policingprogram-1.5339727

Dominion of Canada. (1889). Annual report of the Department of Indian Affairs for the year ended 31 December 1889. Ottawa: Maclean, Roger \& Co.

DPRA Canada. (2016). A renewed approach to policing in Indigenous communities - Engagement summary report: What we heard. Ottawa: Author.

First Nations Chiefs of Police Association. (2017). The "benign neglect" of policing is failing First Nations communities. Retrieved from https:// www.fncpa.ca/first-nations-chiefs-of-police-call-for-first-nationspolicing-to-be-entrenched-as-an-essential-service/

Government of Canada. (2019). Investing in the middle class: Budget 2019. Ottawa: Author. https://www.budget.gc.ca/2019/docs/ plan/toc-tdm-en.html

Ho, S. (2020). Defund the police? This is how much Canadian cities spend. CTV News. Retrieved from https://www.ctvnews. $\mathrm{ca} /$ canada/defund-the-police-this-is-how-much-canadian-citiesspend-1.5018506

Hopkins, K. (2019). The last police officer. Anchorage Daily News. Retrieved from https://www.adn.com/alaska-news/lawless/2019/10/24/the-last-police-officer/

Huey, L., \& Ricciardelli, R. (2015). "This isn't what I signed up for": When police officer role expectations conflict with the realities of general duty police work in remote communities. International Journal of Police Science \& Management, 17(3), 194-203.

Hunter-Courchene Consulting Group. (2014). Comprehensive review of the First Nations Policing Program: National report from the community engagement sessions. Ottawa: Author.

Indian and Northern Affairs. (1971). Report of task force: Policing on reserves. Ottawa: Author.

Indigenous and Northern Affairs Canada. (2019). National overview of the community well-being index, 1981 to 2016. Ottawa: Author.
Indigenous and Northern Affairs Canada. (2020). Welcome to first nation profiles. Retrieved from https://fnp-ppn.aadnc-aandc.gc.ca/fnp/ Main/index.aspx? lang=eng

Indigenous Services Canada. (2019). Investing to support the creation of an Indigenous Fire Marshal Office (News Release, August 16). Retrieved from https://www.canada.ca/en/indigenous-servicescanada/news/2019/08/investing-to-support-the-creation-of-anindigenous-fire-marshal-office.html

Ipsos. (2020). Factum: Canadians divided on whether to defund the police: $51 \%$ support the idea, $49 \%$ oppose it. Retrieved from https:// www.ipsos.com/sites/default/files/ct/news/documents/2020-07/ defundpolice-pressrelease-2020-07-27-vl.pdf

Jacobs, M. C. (2012). Assimilation through incarceration: The geographical imposition of Canadian law over Indigenous peoples. Unpublished doctoral thesis. Kingston: Queen's University.

Jones, R. P. (2020). Ottawa police to restructure, focus on community policing and social services. CBC News. Retrieved from https:// www.cbc.ca/news/canada/ottawa/ottawa-police-changes-chiefdefund-1.5664812

Jones, N. A., Ruddell, R., \& Summerfield, T. (2019). Community policing: Perceptions of officers policing Indigenous communities. Canadian Journal of Criminology and Criminal Justice, 61 (1), 41-65.

Kempa, M. (2014). Understanding the historical relationship between economics and change in policing: A policy framework. Ottawa: Canadian Police College.

Kiedrowski, J. (2013). Trends in Indigenous policing models: An international comparison. Ottawa: Compliance Strategy Group.

Kiedrowski, J. (2017). Review of policing services for Tk'emlúps te Secwépemc, Skeetchestn and Whispering Pine Clinton. Ottawa: Compliance Strategy Group.

Kiedrowski, J., Jones, N. A., \& Ruddell, R. (2017). "Set up to fail?" An analysis of self-administered Indigenous police services in Canada. Police Practice and Research, 18(6), 584-598.

Kiedrowski, J., Melchers, R. F., Petrunik, M., \& Ruddell, R. (2015). Amalgamation of police services. Ottawa: Public Safety Canada.

Kiedrowski, J., Petrunik, M., \& Irving, M. (2020). An exploratory study of the apparent reluctance of Indigenous Canadians residing on reserve to complain against the Royal Canadian Mounted Police. Unpublished manuscript.

Kiedrowski, J., Petrunik, M., \& Ruddell, R. (2016). Illustrative case studies of First Nations policing program models. Ottawa: Public Safety Canada.

Kiedrowski, J., Ruddell, R., \& Petrunik, M. (2019). Police civilianization in Canada: a mixed methods investigation. Policing and Society: An International Journal of Research and Policy, 29(2), 204-222.

Kumar, M. B., \& Tiepkema, M. (2019). Suicide among First Nations people, Metis and Invit (2011-2016): Findings from the 2011 Canadian census health and environment cohort. Ottawa: Statistics Canada.

Leuprecht, C. (2017). Force 2.0: Fixing the governance, leadership and structure of the RCMP. Ottawa: Macdonald-Laurier Institute.

Leuprecht, C. (2020). Submission re: SECU hearings on systemic racism in policing in Canada. Retrieved from: https://www.ourcommons.ca/ Committees/en/SECU/StudyActivity? studyActivityld = 10892590

Lithopoulos, S. (2015). A literature review on the amalgamation of police services in Canada. Ottawa: Public Safety Canada.

Lithopoulos, S. (2016). Lifecycle of First Nation administered police services in Canada. Ottawa: Public Safety Canada.

Lithopoulos, S., \& Ruddell, R. (2013). Aboriginal policing in Canada: Establishing a research agenda. International Journal of Rural Criminology, 2(1), 101-125. 
Marcoux, J., Nicholson, K., \& Kubinec, V. (2016). Police diversity fails to keep pace with Canadian populations. CBC News. Retrieved from https://www.cbc.ca/news/canada/police-diversity-canada-1.3677952

MacDonald, T., Kiedrowski, J., Prno, J., Gravill, L., and Osborne, M. (2019). Anishinabek Police Service (APS) Organizational Review. Author.

Marchand, M. E., Laneuville, P., Herve, C., \& Levesque, F. (2020). Police services and Inuit in Nunavik (Arctic Quebec). Knowing each other better to help each other better. Montreal: Université Laval.

McDowell, M. G., \& Fernandez, L. A. (2018). Disband, disempower, and disarm: Amplifying the theory and practice of police abolition. Critical Criminology, 26(3), 373-391

McMillan, L. J., Glode-Desrochers, P., \& Marshall, P. (2020). Examining police practices in Mi'kma'ki pathways to positive policing relationships. Retrieved from https://www.publicsafety.gc.ca/cnt/rsrcs/ pblctns/rvw-plc-prctcs-stf/rvw-plc-prctcs-stf-en.pdf

Meares, T. L. (2017). Policing: A public good gone bad. Boston Review. Retrieved from https://bostonreview.net

Menard, S. (2002). Short- and long-term consequences of adolescent victimization. Washington, DC: Office of Juvenile Justice and Delinquency Prevention.

Montgomery, R., \& Griffiths, C. T. (2017). Contemporary policing responsibilities. Ottawa: Public Safety Canada.

Morin, R., \& Morin, C. (2019). Policing Native American lands in the United States. In J. F. Albrecht, G. den Heyer, \& P. Stanislas (Eds.) Policing and minority communities (pp. 181-193). Springer.

Mugford, R. (2020). FNPP populations served. Unpublished Public Safety Canada data.

Murphy, C. (1999). The current and future state of police research and policy in Canada. Canadian Journal of Criminology, 41 (2), 205-216.

Murphy, C. (2004). The rationalization of Canadian public policing. Canadian Review of Policing Research, 1(1). Retrieved from http:// crpr.icaap.org/index.php/crpr/article/view/11/11

Murphy, C., \& Clairmont, D. (1996). First Nations police officers survey. Ottawa: Ministry of the Solicitor General of Canada.

National Inquiry into Missing and Murdered Indigenous Women and Girls. (2019). Reclaiming power and place. Ottawa: Author.

Nilson, C., \& Mantello, B. (2019). Joining the circle: Identifying key ingredients for effective police collaboration within Indigenous communities. Saskatoon: Community Safety Knowledge Alliance.

Nunavik Statistics. (2020). Crimes against the person, Nunavik, 2013-2019. Retrieved from: https://www.nunivaat.org/doc/document/2019-10-17-01.pdf

O'Donnell, V., \& LaPointe, R. (2019). Response mobility and the growth of the Aboriginal identity population, 2006-2011 and 2011-2016. Ottawa: Statistics Canada.

Office of the Aboriginal and Torres Strait Islander Social Justice Commissioner. (1996). Indigenous deaths in custody 1989-1996. Sydney: Human Rights and Equal Opportunity Commission.

Office of the Auditor General of Canada (OAG). (2014). Chapter 5: First Nations Policing Program-Public Safety Canada. 2014 Spring Report of the Auditor General of Canada. Ottawa: Author.

Perreault, S. (2020). Gender-based violence: Unwanted sexual behaviours in Canada's territories, 2018. Ottawa: Canadian Centre for Justice Statistics.

Prairie Research Associates. (2006). Evaluation of the First Nations policing program: Final report. Winnipeg: Author.

Promislow, J., \& Metallic, N. (2018). Realizing Aboriginal administrative law. In C. M. Flood \& L. Sossin (Eds.), Administrative law in context (pp. 87-100). Emond Publishing.
Public Safety Canada. (2010). 2009-2010 evaluation of the First Nations policing program. Ottawa: Author.

Public Safety Canada. (2012). First Nations policing policy: Program performance and analysis. Ottawa: Public Safety Canada.

Public Safety Canada. (2016). 2014-2015 evaluation of the First Nations policing program. Ottawa: Author.

Public Safety Canada. (2019). Policing in Indigenous communities: First Nations Policing Programs. Retrieved from https://www.publicsafety. gc.ca/cnt/cntrng-crm/plcng/brgnl-plcng/index-en.aspx

Ricciardelli, R. (2018). "Risk it out, risk it out": Occupational and organizational stresses in rural policing. Police Quarterly, 21 (4), 415-439.

Rigakos, G. S. (2008). Plural policing in Saskatchewan First Nations. Ottawa: Aboriginal Policing Directorate of Public Security and Emergency Preparedness Canada.

Rogers, S. (2019). Nunavik police force faces staffing shortage. Nunatsiaq News. Retrieved from https://nunatsiaq.com/

Rotenberg, C. (2019). Police-reported violent crimes against young women and girls in Canada's provincial north and territories, 2017. Ottawa: Canadian Centre for Justice Statistics.

Roy, J., \& Marcellus, S. (2019). Homicide in Canada, 2018. Ottawa: Canadian Centre for Justice Statistics.

Ruddell, R. (2017). Policing rural Canada: The police, partners and public safety. de Sitter Publications.

Ruddell, R., \& Jones, N. A. (2014). The economics of Canadian policing five years into the great recession. Regina: Collaborative Centre for Justice and Safety.

Ruddell, R., \& Jones, N. A. (2020). Policing the "middle of nowhere": Officer working strategies in isolated communities. Policing: A Journal of Policy and Practice, 14(2), 414-427.

Ruddell, R., Lithopoulos, S., \& Jones, N. A. (2014). Crime, costs, and wellbeing: Policing Canadian Aboriginal communities. Policing: An International Journal of Police Strategies \& Management, 37(4), 779-793.

Samuelson, L. (1993). Aboriginal policing issues: A comparison of Canada and Australia. Ottawa: Ministry of the Solicitor General of Canada.

Social Sciences and Humanities Research Council. (2020). Awards. Retrieved from: https://www.sshrc-crsh.gc.ca/results-resultats/ award_search-recherche_attributions/index-eng.aspx

State Services Commission. (2012). Formal review of the New Zealand police. Wellington: Author.

Standing Committee of Attorneys' General Working Group on Indigenous Justice. (2010). National Indigenous law and justice framework 2009-2015. Commonwealth of Australia.

Solicitor General Canada. (1996). First Nations policing policy. Ottawa: Author

Solicitor General for Ontario. (1974). Task force on policing in Ontario. Toronto: Author.

The Allen Consulting Group. (2010). Independent review of policing in remote Indigenous communities in the Northern Territory. Melbourne: Author.

Viens Commission. (2019). Final report. Quebec City: Author.

Vitale, A. S. (2017). The end of policing. New York: Verso.

Wakeling, S., Jorgensen, M., Michaelson, S., \& Begay, M. (2001). Policing on American Indian reservations (Research report). Washington: U.S. Department of Justice.

Watt, S. (2008). RCMP FNCPS review: A review of the First Nation Community police service in British Columbia for Canada, the province of BC and the CTA Steering Committee. Vancouver: CMLS Global

Wells, L. E., \& Falcone, D. N. (2008). Rural crime and policing in American Indian communities. Journal of Rural Social Services, 23(2), 199-225.

Wooff, A. (2017). Soft policing in rural Scotland. Policing: A Journal of Policy and Practice, 11(2), 123-131. 


\section{CASES CITED}

Delgamuukw v. British Columbia, [1997] 3 S.C.R. 1010

R. v. Marshall [1999] 3 S.C.R. 456

R. $\vee$ Pamajewon [1996] 2 S.C.R. 821

R. v. Sparrow [1990] 1 S.C.R. 1075

R. v. Van der Peet [1996] 2 S.C.R. 507

Tsilhqot'in Nation v. British Columbia [2014] 2 S.C.R. 256 